\title{
PUBLIC KNOWLEDGE CONCERNING CARDIOPULMONARY RESUSCITATION AND AUTOMATED EXTERNAL DEFIBRILLATOR SKILLS IN LITHUANIA
}

\author{
Pranas Šerpytis ${ }^{1,2,3}$, Tomas Tamošiūnas ${ }^{1,2}$, Andžela Slušniené ${ }^{4}$, Sigita Glaveckaite ${ }^{1,3}$, \\ Greta Kezytė ${ }^{1}$ Indrè Urbanavičiūtė ${ }^{1}$, Aleksandras Laucevičius ${ }^{1,3}$ \\ ${ }^{1}$ Faculty of Medicine, Vilnius University, Vilnius, Lithuania
}

${ }^{2}$ Centre of Emergency medicine, Vilnius University Hospital Santariskiu Clinics, Vilnius, Lithuania, ${ }^{3}$ Clinic of Cardiovascular Diseases, Vilnius University Hospital Santariskiu Clinics, Vilnius, Lithuania, ${ }^{4}$ Centre of Innovative Medicine, Vilnius, Lithuania

Key words: cardiopulmonary resuscitation, automated external defibrillator, sudden cardiac arrest, cardiovascular diseases, public education.

\begin{abstract}
Summary
Introduction: Cardiovascular diseases (CVD) are the leading cause of mortality worldwide. Even in $65 \%$ of cases the first registered rhythm after cardiac arrest is ventricular fibrillation (VF) which can be restored to sinus rhythm by defibrillation. European Resuscitation Council guidelines (2010) highlight the importance of automated external defibrillator (AED) and encourage further AED program development and device installation in public places.

The aim and methods: To assess public knowledge about cardiopulmonary resuscitation (CPR) and capability of using AED in five largest cities of Lithuania. The anonymous survey was conducted in public areas (shopping malls, stations, city squares). Only adults (aged 18-65 years) who claimed to have knowledge about CPR were interviewed.

Results: 130 (76.9\%) of respondents described their knowledge about CPR as inadequate. In a hypothetical 3-step situation, where a person clenches fists over his chest and falls, only $16.6 \%$ of respondents would act correctly according to the guidelines. Only 29\% (49) knew what AED was, those aware of AED - almost all correctly stated the principle of managing the device and indications of its usage. The main sources of information regarding AED: training at the office $28.6 \%$ (14), television $28.6 \%$ (14), driving courses $22.4 \%$ (11); about CPR - dri-
\end{abstract}

ving courses $70.4 \%$ (119), school $46.7 \%$ (79), television $26 \%$ (44) and training at the office $24.9 \%$ (42). $81.6 \%$ of respondents would participate in CPR and AED courses, if they were free of charge. Conclusions: Lithuanian's knowledge about CPR is insufficient, only every third person knows what AEDs are. Community education and training on CPR and AEDs use are needed. The majority of respondents would attend CPR and AED training if it was free of charge.

\section{Introduction}

Cardiovascular diseases (CVD) are the leading cause of mortality in the industrialized world [1]. A sudden cardiac death accounts for about $60 \%$ of cardiac deaths [2]. The analysis of patient's experienced cardiac arrest demonstrated that in $73 \%$ of cases cardiac arrest was the first expression of CVD and patients were asymptomatic before this event [3]. The incidence of out-of-hospital cardiac arrest (OHCA) treated for all rhythms by emergency medical service systems varies between 38 and 86 per 100000 inhabitants [4]. A statistical probability to witness a case of a sudden death is 1 of 2600 in Lithuania. Even in 65 $\%$ of cases the first registered rhythm after cardiac arrest is ventricular fibrillation (VF) which can be restored to sinus rhythm by defibrillation. Nowadays a public input is highlighted - CPR and AED use by bystanders as early as possible is relevant in order to improve outcomes of those who experience a sudden cardiac arrest. The establishment and development of AED programs in public places are encouraged [5-7]. Our study was conducted in places where citizens have statistically the highest chance to witness a sudden death and AED implementation is advised [8]. Mos- 
tly sudden death happens at home (60-80\% of cases) [9]. Nevertheless up to $40 \%$ of cases of sudden death happen in public places. In these cases immediate CPR and early

Table 1. Used questionnaire - part I

\begin{tabular}{|c|c|c|}
\hline Questionnaire - part I & & Possible answers \\
\hline $\begin{array}{l}\text { Do you know how to provide } \\
\text { CPR in case of sudden death? }\end{array}$ & \multicolumn{2}{|c|}{ Yes/No } \\
\hline $\begin{array}{l}\text { Have you ever done CPR to } \\
\text { someone? }\end{array}$ & \multicolumn{2}{|c|}{ Yes/No } \\
\hline $\begin{array}{l}\text { How would you describe your } \\
\text { CPR knowledge? }\end{array}$ & \multicolumn{2}{|c|}{ Sufficient/Insufficient } \\
\hline $\begin{array}{l}\text { How/Where have you learned } \\
\text { CPR? } \\
\text { (can pick } \geq 1 \text { answer/s) }\end{array}$ & \multicolumn{2}{|c|}{$\begin{array}{l}\text { - school - driving courses } \\
\text { - specialized literature - Internet } \\
\text { - television - correspondence } \\
\text { - training in the office - other (write it down) }\end{array}$} \\
\hline \multirow[t]{3}{*}{$\begin{array}{l}\text { What would you do if a person } \\
\text { suddenly clenches fists over his } \\
\text { chest and falls? (choose one } \\
\text { correct answer in each step) }\end{array}$} & Step 1 & $\begin{array}{l}\text { - I would call for help } \\
\text { - I would check if person is breathing } \\
\text { - I would check if person is breathing and } \\
\text { would take his pulse } \\
\text { - I would take no actions, I am not a me- } \\
\text { dical person }\end{array}$ \\
\hline & Step 2 & $\begin{array}{l}\text { - I would take no further actions, to pre- } \\
\text { vent causing any damage } \\
\text { - I would check if person is breathing } \\
\text { - I would call for help } \\
\text { - I would check if person is breathing and } \\
\text { would take his pulse }\end{array}$ \\
\hline & Step 3 & $\begin{array}{l}\text { - If a person is not breathing, I would do } \\
\text { chest compressions and rescue breaths } \\
\text { - I would take no further actions, to pre- } \\
\text { vent causing any damage } \\
\text { - If a person is not breathing, I would do } \\
\text { chest compressions, but not the rescue } \\
\text { breaths } \\
\text { - If a person is not breathing, I would } \\
\text { do rescue breaths and only after them - } \\
\text { chest compressions }\end{array}$ \\
\hline $\begin{array}{l}\text { When, in your opinion, CPR } \\
\text { should be started? }\end{array}$ & \multicolumn{2}{|c|}{$\begin{array}{l}\text { - When a person is breathing, but unconscious } \\
\text { - When the pulse is very rapid } \\
\text { - When blood pressure significantly drops } \\
\text { - When there is no breathing } \\
\text { - Don't know }\end{array}$} \\
\hline $\begin{array}{l}\text { How to carry out CPR cor- } \\
\text { rectly? }\end{array}$ & \multicolumn{2}{|c|}{$\begin{array}{l}\text { - Perform } 30 \text { chest compressions and } 2 \text { rescue breaths. } \\
\text { Continue } 4-5 \text { minutes. After that CPR no longer make sen- } \\
\text { se. } \\
\text { - Perform } 30 \text { chest compressions and } 2 \text { rescue breaths. } \\
\text { Continue until paramedics arrive. } \\
\text { - Perform } 15 \text { chest compressions and } 2 \text { rescue breaths. } \\
\text { Continue until paramedics arrive. } \\
\text { - Perform only } 30 \text { chest compressions because it is possible } \\
\text { to get infected by doing rescue breaths. } \\
\text { - It is better not to do CPR, because non-medic could break } \\
\text { the victim's ribs. } \\
\text { - Don't know. }\end{array}$} \\
\hline Do you know what AED is? & \multicolumn{2}{|c|}{ Yes/No } \\
\hline
\end{tabular}

defibrillation would improve the outcomes. According to various scientific studies, conducted in the United States of America (USA) and Japan, the use of AED improves the survival almost twice in cases of a sudden death of cardiac origin $[5,10]$.

The aim of this study was to assess knowledge on the CPR and the AED use among the Lithuanian population from five largest cities of Lithuania (Vilnius, Kaunas, Klaipeda, Siauliai, Panevezys) and determine the sources from which people commonly become aware of the CPR and the AED.

\section{Material and methods}

The anonymous survey was conducted by personally interviewing randomly encountered people. The survey was carried out in places of mass gathering (shopping centers, bus and railway stations, city squares) in the five largest cities of Lithuania (Vilnius, Kaunas, Klaipeda, Siauliai and Panevezys). The survey was conducted from January to March 2015. The choice of the number of respondents had to retain a proportion that reflects the population of the current city. Only adult respondents (aged 18-62) with knowledge of the CPR were interviewed, while those who did not have knowledge about CPR or AED were not interviewed, but the number of these participants was noted. Provided survey consisted of two main parts: the first part - questions about the CPR (Table 1), the second part - questions about AED (Table 2). Respondents, who did not have knowledge about AED, filled only the first part of the questionnaire. The questionnaire 
consisted of multiple-choice questions with possible one or more correct answers. Questions were based on and evaluated according to the 2010 European Resuscitation Council

Table 2. Used questionnaire - part II

\begin{tabular}{|c|c|}
\hline Questionnaire - part II & Possible answers \\
\hline $\begin{array}{l}\text { Do you know what sign marks } \\
\text { the place where you can find a } \\
\text { defibrillator? }\end{array}$ & Yes/No \\
\hline $\begin{array}{l}\text { How/Where have you learned } \\
\text { about AED? } \\
\text { (can pick } \geq 1 \text { answer/s) }\end{array}$ & $\begin{array}{l}\text { - school - driving courses } \\
\text { - specialized literature - Internet } \\
\text { - television - correspondence } \\
\text { - training in the office - other (write it down) }\end{array}$ \\
\hline $\begin{array}{l}\text { How do you think does a defi- } \\
\text { brillator operate? }\end{array}$ & $\begin{array}{l}\text { - Causes electric shock and it restores a normal heart } \\
\text { function } \\
\text { - Causes electric shock and it restores a normal breat- } \\
\text { hing } \\
\text { - Causes electric shock, it stimulates the brain, so the } \\
\text { victim became conscious } \\
\text { - I do not know how it works }\end{array}$ \\
\hline $\begin{array}{l}\text { In what circumstances you are } \\
\text { going to use a defibrillator? }\end{array}$ & $\begin{array}{l}\text { - When a person is unconscious, but breathing } \\
\text { - When a person is not breathing for longer than } 20 \\
\text { minutes } \\
\text { - When there is no heart beat and circulation } \\
\text { - Don't know }\end{array}$ \\
\hline How to use a defibrillator? & $\begin{array}{l}\text { - Defibrillator must be switched on and everybody } \\
\text { should wait for the arrival of paramedics, they will } \\
\text { perform audio commands. } \\
\text { - I should turn on a defibrillator and perform audio } \\
\text { commands: stick electrodes where shown, perform } \\
\text { defibrillation, perform chest compressions } \\
\text { - Don't know }\end{array}$ \\
\hline $\begin{array}{l}\text { How to use safely a defibrilla- } \\
\text { tor? (Mark the statement: true/ } \\
\text { false/ don't know) }\end{array}$ & $\begin{array}{l}\text { 1. When an electric discharge takes place, do not touch } \\
\text { the body of the victim. } \\
\text { 2. When using the defibrillator wear disposable, pro- } \\
\text { tective gloves. } \\
\text { 3. When the defibrillator is used for a drowned person, } \\
\text { his chest must first be drained. } \\
\text { 4. When the defibrillator analyses the rhythm, the pa- } \\
\text { tient can be touched. } \\
\text { 5. The defibrillator can be used when it rains. } \\
\text { 6. When the breathing is restored, electrodes on the } \\
\text { chest must be immediately removed. }\end{array}$ \\
\hline $\begin{array}{l}\text { Who do you think should use } \\
\text { the AED? }\end{array}$ & $\begin{array}{l}\text { - Only a medical person or other trained individuals } \\
\text { providing emergency assistance. } \\
\text { - Each member of the society. }\end{array}$ \\
\hline $\begin{array}{l}\text { Would you like to take part in } \\
\text { the training on the cardiopul- } \\
\text { monary resuscitation (CPR) } \\
\text { and defibrillation? }\end{array}$ & $\begin{array}{l}\text { - Yes, if it would be free of charge. } \\
\text { - I would take part even if I was charged. After all, you } \\
\text { can save human lives } \\
\text { - Don't know } \\
\text { - I would not take part because only medics should } \\
\text { know how to do CPR }\end{array}$ \\
\hline $\begin{array}{l}\text { Are you going to use an AED } \\
\text { without special training? }\end{array}$ & Yes/No/ Don't know \\
\hline $\begin{array}{l}\text { Do you know where you can } \\
\text { find defibrillator in your city? }\end{array}$ & $\begin{array}{l}\text { - Yes (write it down) } \\
\text { - No, I do not know } \\
\text { - There are no AEDs in my city }\end{array}$ \\
\hline
\end{tabular}

guidelines. No assistance was given to participants when they were completing the survey.

\section{Results}

9 out of 178 randomly encountered participants $(5.1 \%)$ stated that they had no basic knowledge of CPR. Further statistical analysis consisted of data of remaining 169 surveyed respondent's answers. Table 3 shows basic demographic data representing surveyed respondents. $130(76.9 \%)$ of all respondents described their CPR knowledge as insufficient. The main sources of information from which respondents had heard of CPR: driving courses $70.4 \%$ (119), school 46.7\% (79), television $26 \%$ (44) and training at the office $24.9 \%$ (42). $75.6 \%$ of all respondents who noted that they had learned CPR from driving courses described their CPR knowledge as insufficient. In a hypothetical 3-step situation where a person clenches fists over his chest and falls only $16.6 \%$ of all respondents would act correctly according to the guidelines (Figure 1). 75.1\% (127) of all respondents correctly indicated that the CPR actions should be initiated when breathing stops. $33.7 \%$ (57) of all respondents correctly stated chest compression to rescue breaths ratio of $30: 2$, though $37.9 \%(64)$ of all the people surveyed noted that compression and breath ratio should be 15:2 and even $3 \%$ (5) of respondents stated that it is better not to resuscitate because the lack of knowledge of medical training can break the ribs during chest compressions.

Only $29 \%$ (49) out of all respondents knew what the AED was, $57.1 \%$ (28) of them knew what AED sign looked like (Figure 2). The main sources of information from which respondents had heard about the AED: training at the of- 
Table 3. Basic demographic data of the respondents

\begin{tabular}{|c|c|}
\hline Female & $110(65.1 \%)$ \\
\hline Male & $59(34.9 \%)$ \\
\hline Age (mean \pm SD, years) & $32,2 \pm 12,1$ \\
\hline Age range (years) & $18-62$ \\
\hline \multicolumn{2}{|l|}{ Education } \\
\hline General (middle-school) & $2(1.2 \%)$ \\
\hline Secondary (high-school) & $40(23.7 \%)$ \\
\hline Higher (college) & $25(14.8 \%)$ \\
\hline Higher (university) & $102(60.4 \%)$ \\
\hline \multicolumn{2}{|l|}{ Cities } \\
\hline Vilnius & $67(39.6 \%)$ \\
\hline Kaunas & $42(24.9 \%)$ \\
\hline Klaipeda & $19(11.2 \%)$ \\
\hline Siauliai & $24(14.2 \%)$ \\
\hline Panevezys & $17(10.1 \%)$ \\
\hline
\end{tabular}

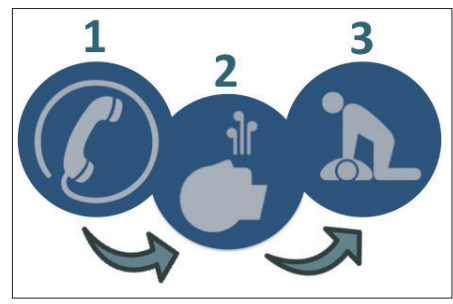

Figure 1. Sequence of actions based on European Resuscitation Council 2010 guidelines: Step 1 - call for help, Step 2 - check for breathing, Step 3 - rescue breaths and chest compressions (ERC guidelines stress the importance and benefit of chest compressions alone in a situation when rescue breaths are unacceptable for person performing CPR)

fice $28.6 \%$ (14), television $28.6 \%$ (14), driving courses $22.4 \%$ (11). Respondents, who were aware of the AED, 93.9\% (46) and $81.6 \%$ (40) of them knew the operation principle and indications of its usage. Moreover, the vast majority of the interviewees $-85.7 \%$ (42) - correctly explained how to use the device. The major part of the interviewees would be well-advised during the electric discharge $-87.7 \%$ (43) of the interviewees suggested that a victim cannot be touched at that time. The majority of the respondents $61.2 \%$ (30) indicated that the AED should be used by every member of society, if necessary, but only $24.5 \%$ (12) of interviewed people would use it themselves without special preparation. $81.6 \%$ of all people from the study would participate in CPR and AED courses, if they were free of charge. 8 out of 169 respondents had been in a situation when they needed to perform CPR. 7 of them properly stated the sequence of steps that should be carried out near the collapsed man in a hypothetical situation. 6 respondents correctly answered when exactly CPR had to be performed and only 4 respondents knew when exactly CPR had to be performed. Half of the people who had real resuscitation experience knew what AED was and its mechanism of operation. 3 out of 8 interviewees rightly pointed out when to use AID. Analysis of respondent's knowledge according to the place of residence is given in Figure 3.

\section{Discussion}

According to the conducted survey a considerably large proportion of citizens participated in the initial CPR training in the past (mostly in driving courses). Unfortunately, the greater part of respondents is not satisfied with their knowledge. The situation is similar in other European countries (Slovenia and Poland), where public education and implementation of AED programs stand behind Western countries [11-13]. Active educational programs initiated by American Heart Association (AHA) in USA are designed to educate and teach society about the importance and techniques of basic life support skills. Active AHA activities had the effect: CPR performed by bystanders in 2005 - 2006 accounted for $28.2 \%$ and in 2012 increased up to $36.3 \%$, also the number of cases increased where

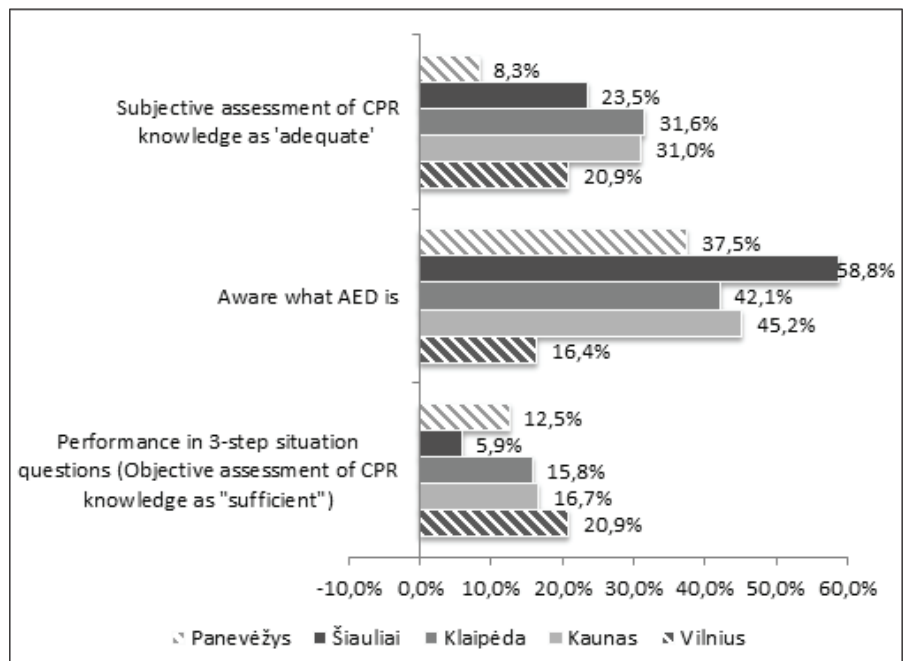

Figure 3. Respondent's assessment of knowledge by the place of residence 
bystanders used accessible AED in a public place. There is a tendency of improvement in prehospital and hospital survival rates, especially in neurological outcomes [14]. The other study, conducted in USA, found that survival after cardiac arrest improved from $7.1 \%$ in 2010 to $9.7 \%$ in 2013. The latter improvement is associated with early CPR performed by bystanders. Neurological functions of those victims, who suffer cardiac arrest, decline less when victim is started to resuscitate by witnesses. These results are associated with large-scale educational programs and CPR/ AED training benefits [15], also there is a great importance in advanced treatment of cardiac arrest patients. PAROS (The Pan Asian Resuscitation Outcomes Study) included 7 Asian countries (Japan, Singapore, South Korea, Malaysia, Taiwan, Thailand, United Arab Emirates) and showed that in countries, where active educational activities were organized, frequency of CPR performed by witnesses increases up to $40.2 \%$ in Japan and up to $40.9 \%$ in South Korea [3]. Japan started educational programs in general schools, in firefighters and driver training courses. Although AED importance is widely recognized, according to PAROS data, only $1 \%$ of cardiac arrest victims were defibrillated by bystanders using AED [3]. European Resuscitation Council guidelines, published in 2010, stressed the importance of AED, further development of AEDs programs and implementation in public places [8]. Study conducted in Denmark illustrates the effectiveness of this recommendation. AED network in Denmark is comprised from 807 devices installed in urban and rural areas. Danish study showed that in case of cardiac arrest witnessed by layperson the possibility to survive greatly increases. It was found that patients, who had initial shockable rhythm and were defibrillated using AED, survival rate was up to $69 \%$ with good neurological outcomes (Cerebral Performance Category (CPC) 1, i. e. good cerebral performance) [9].

We believe that small percentage of respondents who are aware of AED should not be seen as a system failure. Our research shows that people who already know what AED is and understands the basic principles of its usage can successfully apply it in the event of emergency. Studies conducted in other countries indicate that the benefit of AED programs is observed only after a considerable amount of time from the start. At present, scientists and experts held a lively debate about the installation of AED in crowded places; international recommendations also stress the benefits of these devices. Our study showed that considering current situation in Lithuania, devices would remain unused due to lack of knowledge and fear of doing harm. We would like to emphasize that AED program success is determined not only with the number of AEDs installed but also with a parallel process of public education. The main identified sources of information - driving and workplace first aid courses, therefore quality improvement and assurance should be given with special attention. As it was mentioned above, the first aid training, as a part of driving courses, does not meet any expectations of drivers. A number of respondents gained knowledge about CPR at school. It is particularly important to ensure continuing high-quality training in educational institutions which would be attractive to young people. Nearly one-third of respondents learned about AED from television, which is also a very important way to spread the knowledge of basic life support techniques as it reaches a large number of people.

We believe that there is a need to start nationwide educational programs considering not only implementation of devices but also using all possible ways to educate the society.

\section{Conclusions}

The majority of citizens of five largest cities of Lithuania claim to have knowledge about CPR, but 3 out of 4 respondents describe it as insufficient.

The majority of respondents name driving courses as the main source of information. However, acquired knowledge does not satisfy the respondents.

Knowledge of population about AED is insufficient, because only one third of respondents knew what AED is. Almost all of those who know about AED correctly state the principle of operation of the device and the indications for its use.

The vast majority of respondents note that they would participate in CPR and AED training if it was free of charge. A nationwide educational program is required to help to improve public's knowledge about CPR and AED.

\section{References}

1. http://www.who.int/mediacentre/factsheets/fs317/en/Accessed April 24, 2016.

2. Zheng ZJ, Croft JB, Giles WH, Mensah GA. Sudden cardiac death in the United States, 1989 to 1998. Circulation 2001;104:2158-63.

http://dx.doi.org/10.1161/hc4301.098254

3. Gräsner JT, Böttiger BW, Bossaert L. European Registry of Cardiac Arrest (EuReCa) ONE Steering Committee, EuReCa ONE Study Management Team. EuReCa ONE - ONE month - ONE Europe - ONE goal. Resuscitation 2014 Oct;85(10):1307-8. http://dx.doi.org/10.1016/j.resuscitation.2014.08.001

4. Ong MEH, Shin SD, De Souza NNA. et al. Outcomes for outof-hospital cardiac arrests across 7 countries in Asia: The Pan Asian Resuscitation Outcomes Study (PAROS). Resuscitation. 2015 November; 96:100-8. 
http://dx.doi.org/10.1016/j.resuscitation.2015.07.026

5. Puchalski B, Kwasiżur M, Płatek AE, Szymański FM. The use of an automated external defibrillator in a victim of car accident. Kardiol Pol 2014;72(12):1400. http://dx.doi.org/10.5603/KP.2014.0233

6. Weisfeldt ML, Sitlani CM, Ornato JP, Rea T, Aufderheide TP, Davis D. et al. Survival after application of automatic external defibrillators before arrival of the emergency medical system: evaluation in the resuscitation outcomes consortium population of 21 million. J Am Coll Cardiol 2010 Apr 20;55(16):1713-20. http://dx.doi.org/10.1016/j.jacc.2009.11.077

7. Cacko A, Wyzgał A, Galas A, Grabowski M, Filipiak KJ, Opolski G. Availability of automated external defibrillators in the city of Warsaw - status for May 2009. Kardiol Pol 2010;68(1):41-46.

8. Monsieurs KG, Nolan JP, Bossaert LL. et al. European resuscitation Council Guidelines for resuscitation 2015 Section 1. Executive summary. Resuscitation 2015 Oct;81(10):1-80. http://dx.doi.org/10.1016/j.resuscitation.2015.07.038

9. Nielsen AM, Folke F, Lippert FK, Rasmussen LS. Use and benefits of public access defibrillation in a nation-wide network. Resuscitation 2013 Apr;84(4):430-4. http://dx.doi.org/10.1016/j.resuscitation.2012.11.008

10. Kitamura T, Iwami T, Kawamura T, Nagao K, Tanaka H, Hiraide A. et al. Nationwide public-access defibrillation in Japan. N Engl J Med 2010 Mar 18;362(11):994-1004. http://dx.doi.org/10.1056/NEJMoa0906644

11. Rajapakse R, Noč M, Kersnik J. Public knowledge of cardiopulmonary resuscitation in Republic of Slovenia. Wien Klin Wochenschr 2010 Dec;122(23-24):667-72. http://dx.doi.org/10.1007/s00508-010-1489-8

12. Wroblewska I. Public access defibrillation in Opole city in Poland. Experimental and Clinical Cardiology (2014) 20: 4567-4581.

13. Kozłowski D, Kłosiewicz T, Kowalczyk A. et al. The knowledge of public access to defibrillation in selected cities in Poland. Archives of Medical Science:AMS 9, no. 1, 2013 Feb 21.

http://dx.doi.org/10.5114/aoms.2013.33345

14. Chan PS, McNally B, Tang F, Kellermann A. Recent trends in survival from out-of-hospital cardiac arrest in the United States. Circulation 2014 Nov 18;130(21):1876-82. http://dx.doi.org/10.1161/CIRCULATIONAHA.114.009711

15. Malta Hansen C, Kragholm K, Pearson DA. et al. association of bystander and first-responder intervention with survival after out-of-hospital cardiac arrest in North Carolina, 2010-2013. JAMA. 2015 Jul 21;314(3):255-64.

http://dx.doi.org/10.1001/jama.2015.7938

\section{VISUOMENĖS ŽINIOS APIE PRADINI GAIVINIMA IR AUTOMATINIŲ IŠORINIŲ DEFIBRILIATORIŲ NAUDOJIMĄ LIETUVOJE}

\section{P. Šerpytis, T. Tamošiūnas, A. Slušnienė, S. Glaveckaitė,}

\section{G. Kezytė, I. Urbanavičiūtė, A. Laucevičius}

Raktažodžiai: pradinis gaivinimas, automatinis išorinis defibriliatorius, staigus širdies sustojimas, koronarinė širdies liga, visuomenès žinios.

Santrauka

Ivadas. Koronarinė širdies liga yra viena dažniausių mirties priežasčių pasaulyje. Net $65 \%$ širdies sustojimo atveju pirmas registruojamas ritmas yra skilvelių virpejjimas, kuris gali būti atstatytas ị sinusinį ritmą defibriliuojant. Europos gaivinimo tarybos gairès pabrèžia automatinių išorinių defibriliatorių (AID) svarbą ir skatina tolesnị šių prietaisų ịrengimą viešose vietose.

Tikslas ir metodai. İvertinti 5 didžiujų Lietuvos miestų gyventojų žinias apie pradini gaivinimą (PG) ir AID naudojimą. Anoniminė apklausa buvo atlikta viešose vietose (prekybos centruose, geležinkelių ir autobusų stotyse, miestų aikštėse). Apklausti suaugusieji (amžius 18-65 metai), kurie teige turintys žinių apie PG.

Rezultatai. 130 (76,9\%) respondentu apibūdino savo žinias apie PG kaip nepakankamas. Hipotetinèje 3 žingsnių situacijoje, kai žmogus griebiasi už krūtinès ir susmunka tik 16,6\% respondentų reaguotų teisingai remiantis gairèmis. Tik 29\% (49) žinojo, kas yra AID, iš žinančių dauguma teisingai nurodè prietaiso veikimo principus ir panaudojimo indikacijas. Pagrindiniai informacijos šaltiniai apie AID: mokymai darbo vietoje 28,6\% (14), televizija $28,6 \%$ (14), vairavimo kursai $22,4 \%$ (11); apie pradini gaivinima - vairavimo kursai 70,4\% (119), mokykla 46,7\% (79), televizija $26 \%$ (44) ir mokymai darbo vietoje 24,9\% (42). 81,6\% respondentu dalyvautų PG ir AID mokymuose, jeigu jie būtų nemokami.

Išvada. Didžioji apklaustų pagrindinių Lietuvos miestų gyventojų dalis teigia turintys žinių apie PG, tačiau objektyviai vertinant jos yra nepakankamos. Kas trečias žmogus žino, kas yra AID. Didžioji dalis jų žino AID veikimo mechanizmą ir naudojimo pagrindus. Reikalingas visuomenès švietimas ir mokymas, juo labiau, kad didžioji dalis respondentų nurodo, jog dalyvautų mokymuose, jeigu jie būtų nemokami.

Adresas susirašinèti: pranas.serpytis@santa.lt

Gauta 2016-05-17 